\title{
SYNTHESIS, STRUCTURAL AND SPECTROSCOPIC CHARACTERIZATION OF THALLIUM(I) ACESULFAMATE*
}

\author{
Enrique J. Baran ${ }^{1 *}$, Beatriz S. Parajón-Costa ${ }^{1}$, Gustavo A. Echeverría ${ }^{2}$, Oscar E. Piro ${ }^{2}$ \\ ${ }^{1}$ Centro de Química Inorgánica (CEQUINOR, CONICET/UNLP), Facultad de Ciencias Exactas, \\ Universidad Nacional de La Plata, C. Correo 962,1900 La Plata, Argentina \\ ${ }^{2}$ Departamento de Física and Instituto IFLP (CONICET), Facultad de Ciencias Exactas, \\ Universidad Nacional de La Plata, 1900 La Plata, Argentina \\ *baran@quimica.unlp.edu.ar
}

\begin{abstract}
The new acesulfamate salt, $\mathrm{TlC}_{4} \mathrm{H}_{4} \mathrm{NO}_{4} \mathrm{~S}$, was prepared by reaction of acesulfamic acid and thallium(I) carbonate in aqueous solution. Its crystal and molecular structure was determined by single crystal $\mathrm{X}$-ray diffraction methods. The substance crystallizes in the monoclinic space group $P 2_{l} / a$, with unit cell parameters $a=7.5844(4) \AA, b=9.7268(5) \AA, c=10.8105(5) \AA, \beta=105.174(6)^{\circ}$, and $Z=4$ molecules per unit cell, and is isostructural with the corresponding sodium, potassium, rubidium and cesium salts. The FTIR and Raman spectra of the compound are also recorded and briefly discussed.
\end{abstract}

Keywords: thallium(I) acesulfamate; synthesis; crystal structure; IR spectra; Raman spectra

\section{СИНТЕЗА, СТРУКТУРНА И СПЕКТРОСКОПСКА КАРАКТЕРИЗАЦИЈА НА ТАЛИУМ(I)АЦЕСУЛФАМАТ}

Синтетизирана е нова ацесулфаматна сол, $\mathrm{TlC}_{4} \mathrm{H}_{4} \mathrm{NO}_{4} \mathrm{~S}$, преку реакција на ацесулфаматна киселина и талиум(I)карбонат во водна средина. Определена е нејзината кристална и молекулска структура со методот на рендгенска дифракција на монокристал. Супстанцата кристализира во моноклиничната просторна група $P 2_{1} / a$, со параметри на елементарната келија $a=7.5844(4) \AA ⿻$, $b=$ 9.7268(5) $\AA, c=10.8105(5) \AA, \beta=105.174(6)^{\circ}$, и $Z=4$, и е изоструктурна со соодветните соли на натриум, калиум, рубидиум и цезиум. Снимени се и накратко дискутирани Фуриеовите трансформни инфрацрвени, како и раманските спектри на соединението.

Клучни зборови: талиум(I)ацесулфамат; синтеза; кристална структура; ИЦ спектри; рамански спектри

\section{INTRODUCTION}

Food additives are substances added intentionally to food to perform certain functions such as to preserve flavor, enhance their taste or appearance, impart color, sweeten or preserve. They play an essential role in the modern food industry, supporting quality and safety. In this context, artificial sweeteners are profusely used in food, beverage, confectionary and pharmaceutical products throughout the world $[1,2]$.
Acesulfame-K, the potassium salt of 6-methyl-1,2,3-oxathiazin-4(3H)-one-2-2-dioxide, first prepared by Clauss and Jensen [3, 4], is one of the most widely used non-caloric artificial sweeteners and has about 200 times the sweetening capacity of sucrose [2, 4]. Its general chemical and biological properties have been thoroughly investigated [14], and its crystal structure has also been determined [5].

From the chemical and structural points of view, the acesulfamate anion (Fig. 1) bears some

\footnotetext{
Dedicated to Academician Gligor Jovanovski on the occasion of his $70^{\text {th }}$ birthday.
} 
resemblance to saccharin (1,2-benzothiazole$3(2 H)$-one-1,1-dioxide), whose coordination capacity has been intensively explored and exploited during the last decades [6]. The study of this ligand constituted, during many years, one of the main research activities of Gligor Jovanovski, which can be considered as a central figure in the development of this peculiar field of chemistry and coordination chemistry.

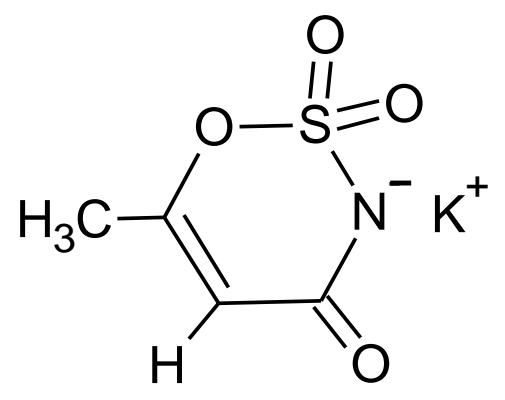

Fig. 1. Schematic structure of potassium acesulfamate

Similar to saccharinate, the acesulfamate anion presents different potential coordination sites: the iminic nitrogen, the carbonylic oxygen and the two sulfonyl oxygen atoms, and it can act as a monodentate, bidentate or bridging ligand, in the same way as saccharinate [6], as demonstrated by a number of acesulfamato metal complexes reported during the last years [7-14].

In order to contribute to a better and wider knowledge of this interesting anion it seemed valuable to investigate some of its simplest salts. In this context, we have prepared and characterized the acesulfamates of ammonium [15], sodium, rubidium and cesium [16] and, extending this work, we have now performed a similar study of the corresponding thallium(I) salt.

\section{EXPERIMENTAL}

\subsection{Materials and measurements}

Potassium acesulfamate was supplied by Fluka and thallium(I) carbonate, along with the other employed reagents were from Merck, analytical grade, and were used as purchased.

Elemental analysis of the compound was performed with a Carlo Erba model EA 1108 elemental analyzer.

The infrared spectra in the spectral range between 4000 and $400 \mathrm{~cm}^{-1}$ were recorded as $\mathrm{KBr}$ pellets with a FTIR-Bruker-EQUINOX-55 spectrophotometer. Raman spectra were obtained with a Perkin Elmer FT-Raman RFs 110/s spectrometer, using the $1064 \mathrm{~nm}$ line of a solid state Nd:YAG laser for excitation.

\subsection{Synthesis of the compound}

Acesulfamic acid was prepared as described by Velaga et al. [17], as follows: To $5.00 \mathrm{~g}$ of potassium acesulfamate dissolved in a small portion of water ( $c a .10 \mathrm{ml}), 6 \mathrm{ml}$ of concentrated $\mathrm{HCl}$ was added drop-wise. The generated acid was extracted with $20 \mathrm{ml}$ of ethyl acetate. After evaporation of the solvent in air a colorless solid was deposited. It was re-crystallized twice from ethyl acetate, generating a deposit of needle-like colorless crystals, after slow evaporation of the solvent in air (m. p. $122-124^{\circ} \mathrm{C}$ ).

For the synthesis of the thallium salt, $0.33 \mathrm{~g}$ $(2.0 \mathrm{mmol})$ of acesulfamic acid was dissolved in $15 \mathrm{ml}$ of distilled water and heated to $75^{\circ} \mathrm{C}$. To this solution, $0.47 \mathrm{~g}(1.0 \mathrm{mmol})$ of $\mathrm{Tl}_{2} \mathrm{CO}_{3}$ was slowly added, under constant stirring. After this addition, the solution was stirred for another 30 $\mathrm{min}$ at the same temperature, and finally left to evaporate in air. After a few days a colorless powder, highly soluble in water, was collected and recrystallized from water (yield: $c a .0 .55 \mathrm{~g}$ ). The purity of the salt was confirmed by elemental analysis. Analysis: $\mathrm{w} \%$ for $\mathrm{TlC}_{4} \mathrm{H}_{4} \mathrm{NO}_{4} \mathrm{~S}\left(M_{\mathrm{f}}=366.48\right)$ are: $\mathrm{C} 13.10, \mathrm{H} 1.09, \mathrm{~N} 3.82, \mathrm{~S} 8.76$; found: C 13.03, H 1.12, N 3.77, S 8.70.

Single crystals adequate for X-ray diffraction studies were selected from the crystalline mass employing a microscope.

\subsection{Crystal structure determination}

The X-ray measurements were performed on an Oxford Xcalibur, Eos, Gemini CCD diffractometer with graphite-monochromated $\operatorname{MoK\alpha }(\lambda=$ $0.71073 \AA$ ) radiation on a small single crystal (less than $0.075 \mathrm{~mm}$ in size) to minimize perturbing effects due to absorption. $X$ ray diffraction intensities were collected ( $\omega$ scans with $\vartheta$ and $\kappa$-offsets), integrated and scaled with CrysAlisPro [18] suite of programs.

The unit cell parameters were obtained by least-squares refinement (based on the angular settings for all collected reflections with intensities larger than seven times the standard deviation of measurement errors) using CrysAlisPro. Data were corrected empirically for absorption employing the multi-scan method implemented in CrysAlisPro.

The structure was solved by direct methods with SHELXS-97 program of the SHELX package 
[19] and the corresponding molecular models developed by alternated cycles of Fourier methods and full-matrix least-squares refinement with the SHELXL-97 of the same package. Anisotropic refinement of the acesulfamate anion showed that its molecular model is better described as a positional disordered structure where the ring oxygen atom occupies two split positions [0.90(2) $\AA$ apart]. The split oxygen atoms were refined with isotropic displacement parameters and occupancies that summed up to one [largest occupancy equal to 0.69(2)]. This same kind of disorder was also observed in the ammonium-acesulfamate salt [15]. Hydrogen atoms were located at the expected geometric positions and refined with the riding model. The methyl $\mathrm{H}$-atoms were treated as a rigid group allowed to rotate during the refinement around the corresponding $\mathrm{C}-\mathrm{C}$ bonds such as to maximize the sum of the electron density at their calculated positions. As a result the $-\mathrm{CH}_{3}$ group converged to a staggered position. Crystal data and structure refinement results are summarized in Table 1.

Tables containing complete information on fractional atomic coordinates and equivalent isotropic displacement parameters of non- $\mathrm{H}$ atoms, atomic anisotropic displacement parameters, and hydrogen atomic positions are available from the authors upon request and have been deposited at the Cambridge Crystallographic Data Centre, under deposition number CCDC 1014479.

Table 1

Crystal data and structure refinement results for thallium(I) acesulfamate

\begin{tabular}{ll}
\hline \hline Empirical formula & $\mathrm{C}_{4} \mathrm{H}_{4} \mathrm{NO}_{4} \mathrm{STl}$ \\
Formula weight & 366.51 \\
Crystal dimension, $\mathrm{mm}^{3}$ & $0.07 \times 0.07 \times 0.03$ \\
Temperature, $\mathrm{K}$ & $297(2) \mathrm{K}$ \\
Crystal system & Monoclinic \\
Space group & $P 2_{1} / a$ \\
$a, \AA$ & $7.5844(4)$ \\
$b, \AA$ & $9.7268(5)$ \\
$c, \AA$ & $10.8105(5)$ \\
$\beta,{ }^{\text {o }}$ & $105.174(6)$ \\
Volume, $\AA^{3} ; Z$ & $769.71(7), 4$ \\
Calculated density, $\mathrm{g} \mathrm{cm}{ }^{-3}$ & 3.163 \\
Absorption coefficient, $\mathrm{mm}^{-1}$ & 21.219 \\
$F(000), \mathrm{e}$ & 656 \\
$\theta$-range for data collection, deg & 3.62 to 26.99 \\
Index ranges & $-9 \leq h \leq 7,-12 \leq k \leq 11,-11 \leq l \leq 13$ \\
Reflections collected & 3494 \\
Independent reflections / $\mathrm{R}_{\text {int }}$ & $1665 / 0.0324$ \\
Observed reflect. $[I>2 \sigma(I)]$ & 1311 \\
Refinement method & Full-matrix least-squares on $\mathrm{F}^{2}$ \\
Data/ restraints/ parameters & $1665 / 0 / 101$ \\
Goodness-of-fit on $F^{2}$ & 1.012 \\
Final indices $R 1 / w R 2[I>2 \sigma(I)]$ & $R 1=0.0324, w R 2=0.0584$ \\
Final indices $R 1 / w R 2($ all data) & $R 1=0.0509, w R 2=0.0657$ \\
Largest peak / hole, e $\AA^{-3}$ & $0.825 /-1.009$ \\
\hline \hline
\end{tabular}

\section{RESULTS AND DISCUSSION}

\subsection{Structural characteristics}

An ORTEP [20] plot of the thallium(I) acesulfamate salt is shown in Fig. 2. Despite the fact that thallium(I) has different S-state electronic configuration than alkaline ions, the salt resulted isomorphous to the M-acesulfamate ( $\mathrm{M}: \mathrm{Na}, \mathrm{K}$, $\mathrm{Rb}, \mathrm{Cs}$ ) family [16]. Bond distances and angles within the acesulfamate molecule in the thallium compound are given in Table 2.

They follow Organic Chemistry's rules, according to values reported for other related salts [15, 16, 21]. Particularly, the short C3-C4 distance of 1.282(10) A confirms the formal double bond character expected for this link. The carbonyl $>\mathrm{C}=\mathrm{O}$ double bond distance is $1.242(8) \AA$ and sulfoxide $\mathrm{S}=\mathrm{O}$ distances are 1.403(6) and 1.427(6) $\AA$. The other ring single bond lengths are $\mathrm{d}(\mathrm{C}-\mathrm{O})=1.420(10) \AA, \mathrm{d}(\mathrm{O}-$ 
$\mathrm{S})=1.646(7) \AA, \mathrm{d}(\mathrm{S}-\mathrm{N})=1.562(6) \AA, \mathrm{d}(\mathrm{C}-\mathrm{N})=$ $1.329(9) \AA$, and d $(\mathrm{C}-\mathrm{C})=1.456(10) \AA$.

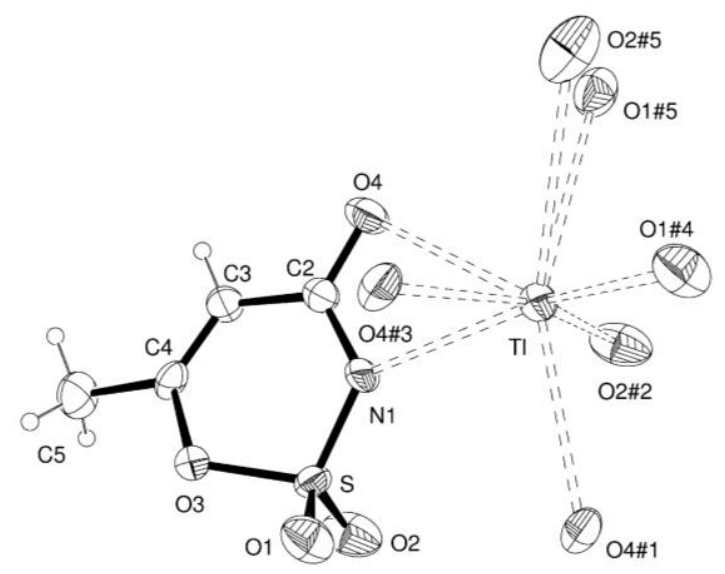

Fig. 2. View of thallium(I) acesulfamate salt showing the labeling of the non-H atoms and their displacement ellipsoids at the $30 \%$ probability level. Metal-ligand short contacts up to

$3.5 \AA$ are indicated by dashed lines. Crystal symmetry operations: (\#1) -x+1/2, y-1/2, -z; (\#2) -x+1, -y, -z; (\#3) x-1/2, $-y+1 / 2, z ;(\# 4)-x,-y,-z ;(\# 5)-x+1 / 2, y+1 / 2,-z$.

Table 2

Bond lengths $(\AA)$ and angles $\left({ }^{\circ}\right)$ of the acesulfamate anion in thallium(I)acesulfamate

\begin{tabular}{lllr}
\hline \hline $\mathrm{C}(2)-\mathrm{O}(4)$ & $1.242(8)$ & $\mathrm{N}(1)-\mathrm{C}(2)-\mathrm{C}(3)$ & $119.1(7)$ \\
$\mathrm{C}(2)-\mathrm{N}(1)$ & $1.329(9)$ & $\mathrm{C}(4)-\mathrm{C}(3)-\mathrm{C}(2)$ & $125.6(7)$ \\
$\mathrm{C}(2)-\mathrm{C}(3)$ & $1.456(10)$ & $\mathrm{C}(3)-\mathrm{C}(4)-\mathrm{O}(3)$ & $119.8(7)$ \\
$\mathrm{C}(3)-\mathrm{C}(4)$ & $1.282(10)$ & $\mathrm{C}(3)-\mathrm{C}(4)-\mathrm{C}(5)$ & $130.3(8)$ \\
$\mathrm{C}(4)-\mathrm{O}(3)$ & $1.420(10)$ & $\mathrm{O}(3)-\mathrm{C}(4)-\mathrm{C}(5)$ & $108.9(7)$ \\
$\mathrm{C}(4)-\mathrm{C}(5)$ & $1.471(10)$ & $\mathrm{C}(2)-\mathrm{N}(1)-\mathrm{S}$ & $122.1(6)$ \\
$\mathrm{N}(1)-\mathrm{S}$ & $1.562(6)$ & $\mathrm{C}(4)-\mathrm{O}(3)-\mathrm{S}$ & $114.6(5)$ \\
$\mathrm{O}(1)-\mathrm{S}$ & $1.427(6)$ & $\mathrm{O}(2)-\mathrm{S}-\mathrm{O}(1)$ & $114.0(4)$ \\
$\mathrm{O}(2)-\mathrm{S}$ & $1.403(6)$ & $\mathrm{O}(2)-\mathrm{S}-\mathrm{N}(1)$ & $113.5(4)$ \\
$\mathrm{O}(3)-\mathrm{S}$ & $1.646(7)$ & $\mathrm{O}(1)-\mathrm{S}-\mathrm{N}(1)$ & $112.2(4)$ \\
& & $\mathrm{O}(2)-\mathrm{S}-\mathrm{O}(3)$ & $111.6(5)$ \\
$\mathrm{O}(4)-\mathrm{C}(2)-\mathrm{N}(1)$ & $119.1(7)$ & $\mathrm{O}(1)-\mathrm{S}-\mathrm{O}(3)$ & $97.3(4)$ \\
$\mathrm{O}(4)-\mathrm{C}(2)-\mathrm{C}(3)$ & $121.9(8)$ & $\mathrm{N}(1)-\mathrm{S}-\mathrm{O}(3)$ & $106.9(4)$ \\
\hline \hline
\end{tabular}

All three acesulfamate binding sites mentioned in the introduction are at short distances from thallium(I) ions. In fact the metal (up to a coordination sphere of $3.5 \AA$ radius) is in an irregular 8-fold polyhedral coordination with six neighboring acesulfamate molecules through the nitrogen and carbonyl oxygen atoms of one molecule, both sulfoxide oxygen atoms of a second one, one sulfoxide oxygen of a third and fourth molecules and one carbonyl oxygen of two other molecules. This coordination around thallium is shown in Fig. 2 and the corresponding metal-ligand short distances are detailed in Table 3.
It is also interesting to mention that the unit cell volumes $\left(V\right.$, in $\left.\AA^{3}\right)$ of the isomorphous series, $V(\mathrm{Na}$-acesulfamate $)=676.52(4)<V(\mathrm{~K}$-acesulfamate $)=726.3(6)<V($ Rb-acesulfamate $)=$ $752.68(5)<V($ Tl-acesulfamate $)=769.71(7)<$ $V($ Cs-acesulfamate $)=822.08(7)$, follows approximately the trend shown by the respective cation ionic radii in eightfold coordination $\left(r\left(\mathrm{Na}^{+}\right)<\right.$ $\left.r\left(\mathrm{~K}^{+}\right)<r\left(\mathrm{Rb}^{+}\right) \approx r\left(\mathrm{Tl}^{+}\right)<r\left(\mathrm{Cs}^{+}\right)\right)[22]$.

Table 3

Short contacts up to 3.5 A around the $T l(I)$ cation in thallium acesulfamate

\begin{tabular}{ll}
\hline \hline Tl-N(1) & $2.764(6)$ \\
Tl-O(4) & $3.112(6)$ \\
Tl-O(4)\#1 & $2.922(6)$ \\
Tl-O(2)\#2 & $2.858(6)$ \\
Tl-O(4)\#3 & $2.925(6)$ \\
Tl-O(1)\#4 & $3.091(6)$ \\
Tl-O(2)\#5 & $3.205(8)$ \\
Tl-O(1)\#5 & $3.308(7)$ \\
\hline \hline \\
Symmetry transformations used to generate \\
equivalent atoms: the same as indicated \\
\multicolumn{2}{c}{ in the caption of Fig. 2. }
\end{tabular}

On the other hand, from the point of view of crystal chemistry, it seems also interesting to compare the main structural characteristics of thallium(I) acesulfamate to those of the corresponding saccharinate. The $\left.\left[\mathrm{Tl}_{2} \text { (saccharinate }\right)_{2}\left(\mathrm{H}_{2} \mathrm{O}\right)\right]_{\mathrm{n}}$, is triclinic (space group $\mathrm{P} \overline{1}$, and $Z=2$ ) and presents a polymeric structure formed by two saccharinate anions, one water molecule and two structurally different $\mathrm{Tl}(\mathrm{I})$ cations, one 8-coordinate and the other 5-coordinate. Saccharinate shows an unprecedented coordination behavior as it acts as chelating ligand through its $N$ and carbonyl atoms with the $N$ atom interacting simultaneously with both metal centers and also the sulfonyl $O$-atoms are involved in bonding [23]. Interestingly, the two polymeric complexes, $[\mathrm{Ag}(\text { acesulfamate })]_{\mathrm{n}}[14]$ and $[\operatorname{Ag}(\text { saccharinate })]_{\mathrm{n}}[24]$, although not identical, show relatively similar structural arrangements.

\subsection{Vibrational spectra}

The FTIR and FT-Raman spectra of the salt are shown in Fig. 3 and the proposed assignments are presented in Table 4 . These assignments were performed on the basis of a recent experimental and DFT-theoretical study of potassium acesulfamate [25], additionally supported by our previous studies $[15,16]$. A first comparison of the spectral 
patterns of $\mathrm{Tl}(\mathrm{I})$ acesulfamate with those of the four isostructural salts [16, 25], immediately shows great similarities between them in both, band distribution and relative intensities.

The proposed spectral assignment is briefly discussed, as follows:

- Stretching vibrations related to $\mathrm{CH}$ and $\mathrm{CH}_{3}$ groups could be clearly identified in the Raman spectrum, and are relatively weak in the IR spectrum.

- As in the previously investigated cases, vibrational modes related to $v(\mathrm{C}=\mathrm{O})$ and $v(\mathrm{C}-\mathrm{C})$ vibrations are strongly coupled and result in two of the most intense IR and Raman bands. Interestingly, the second of this IR bands appears clearly split (the 1593/1551 $\mathrm{cm}^{-1}$ doublet) a fact which was not observed in the case of the isostructural potassium, rubidium and cesium salts [16, 25].

- The strong $1297 \mathrm{~cm}^{-1}$ IR band, and the relatively weaker Raman counterpart (1297/1266 $\left.\mathrm{cm}^{-1}\right)$ is dominated by the $v(\mathrm{CN})$ stretching vibration [25], coupled with some other motions.

- Bands related to the vibrational modes of the sulfonyl moiety appear at somewhat higher energies than in sodium saccharinate and in saccharinato complexes [6, 26-29]. The corresponding $v_{\mathrm{s}}\left(\mathrm{SO}_{2}\right)$ vibration is partially coupled with other vibrational modes [25], as also found in the case of saccharinato complexes [26-29].
- In general, band positions are found at similar energies as in the rubidium and cesium acesulfamates [16], and usually only slightly displaced to somewhat lower wavenumbers.

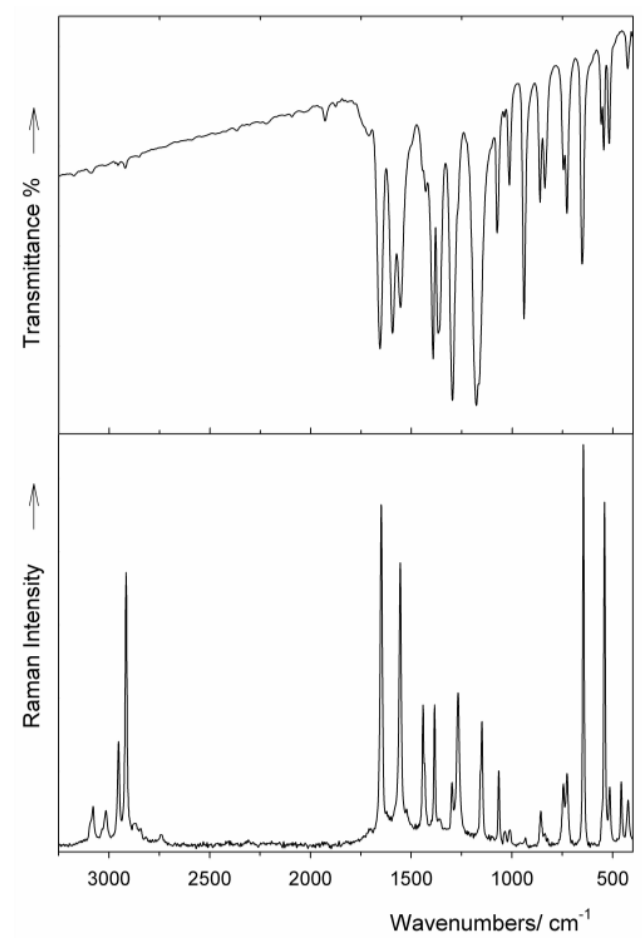

Fig. 3. FTIR spectrum (above) and FT-Raman spectrum (below) from $\mathrm{Tl}(\mathrm{I})$-acesulfamate

Table 4

Assignment of the FTIR- and FT-Raman spectra of Tl(I)-acesulfamate (band positions in $\mathrm{cm}^{-1}$ )

\begin{tabular}{lll}
\hline Infrared & Raman & Assignments \\
\hline $3083 \mathrm{w}$ & $3078 \mathrm{w}, 3016 \mathrm{w}$ & $v(\mathrm{CH})$ \\
$2954 \mathrm{vw}$ & $2953 \mathrm{~m}$ & $v_{\text {as }}\left(\mathrm{CH}_{3}\right)$ \\
$2917 \mathrm{w}$ & $2915 \mathrm{vs}$ & $v_{\mathrm{s}}\left(\mathrm{CH}_{3}\right)$ \\
$1925 \mathrm{w}, 1873 \mathrm{vw}$ & & $\mathrm{Combinations}$ or overtones \\
$1652 \mathrm{vs}, 1593 \mathrm{~m} / 1551 \mathrm{vs}$ & $1648 \mathrm{vs}, 1554 \mathrm{vs}$ & $v(\mathrm{C}=\mathrm{O})+v(\mathrm{C}-\mathrm{C})$ ring \\
$1498 \mathrm{sh}$ & & $\delta\left(\mathrm{CH}_{3}\right)$ \\
$1444 \mathrm{w}, 1429 \mathrm{w}, 1391 \mathrm{~s}$ & $1441 \mathrm{~m}, 1430 \mathrm{sh}, 1384 \mathrm{~m}$ & $\delta\left(\mathrm{CH}_{3}\right)$ \\
$1362 \mathrm{~s}$ & $1362 \mathrm{vw}$ & $v_{\text {as }}\left(\mathrm{SO}_{2}\right)$ \\
$1297 \mathrm{vs}$ & $1297 \mathrm{w}, 1266 \mathrm{~m}$ & $v(\mathrm{CN})+v(\mathrm{OC})+\delta(\mathrm{CCH})$ \\
$1162 \mathrm{vs}$ & $1157 \mathrm{sh}, 1149 \mathrm{~m}$ & $v_{\mathrm{s}}\left(\mathrm{SO}_{2}\right)+v(\mathrm{SN})$ \\
$1069 \mathrm{~s}$ & $1065 \mathrm{~m}$ & $\delta\left(\mathrm{CH}_{3}\right)$ \\
$1013 \mathrm{~s}$ & $1011 \mathrm{~m}$ & $v(\mathrm{OC})+v(\mathrm{SN})$ \\
$939 \mathrm{vs}$ & $1035 \mathrm{vw}, 1015 \mathrm{vw}, 940 \mathrm{vw}$ & $v(\mathrm{OC})+v\left(\mathrm{C}-\mathrm{CH} \mathrm{H}_{3}\right)$ \\
$861 \mathrm{~s}$ & $856 \mathrm{w}$ & $\tau(\mathrm{ring})$ \\
$838 \mathrm{~s}$ & $834 \mathrm{vw}$ & $v(\mathrm{SN})+v(\mathrm{C}-\mathrm{C})+\delta(\mathrm{NCO})$ \\
$746 \mathrm{w} / 727 \mathrm{~s}$ & $744 \mathrm{w} / 726 \mathrm{w}$ & $\tau($ ring $)$ \\
$647 \mathrm{vs}$ & $645 \mathrm{vs}$ & $\delta($ ring $)$ \\
$556 \mathrm{w} / 543 \mathrm{~s}$ & $540 \mathrm{vs}$ & $\delta($ ring $)+\delta\left(\mathrm{SO}_{2}\right)$ \\
$516 \mathrm{~s}$ & $514 \mathrm{w}$ & $\tau($ ring $)$ \\
$459 \mathrm{~s}, 425 \mathrm{~m}$ & $457 \mathrm{w}, 423 \mathrm{w}$ & $\delta($ ring $)$ \\
\hline \hline
\end{tabular}

vs: very strong; s: strong; m: medium; w: weak; vw: very weak; sh: shoulder 


\section{CONCLUSIONS}

We were able to prepare the $\mathrm{Tl}(\mathrm{I})$ acesulfamate, using a general procedure recently developed by us for the synthesis of simple acesulfamate salts. The crystal structure determination shows that this new salt (monoclinic, space group $P 2_{1} / a$ and $Z=4$ ) is isomorphous with the respective sodium, potassium, rubidium and cesium compounds. As expected, the vibrational (IR and Raman) spectra of the $\mathrm{Tl}(\mathrm{I})$-salt resembles closely that of the other four mentioned acesulfamates.

Acknowledgments. This work was supported by the Universidad Nacional de La Plata, by CONICET (PIP 1529), and by ANPCyT (PME06 2804 and PICT06 2315) of Argentina. B.S.P-C., G.A.E. and O.E.P. are members of the Research Career of CONICET.

\section{REFERENCES}

[1] Y. Ni, W. Xiao, S. Kokot, A differential spectrophotometric method for determination of three sulphanilamide artificial sweeteners with the aid of chemometrics, Food Chem., 113, 1339-1345 (2009).

[2] M. Kruger, K. Meister, R. Kava, Low-calorie sweeteners and other sugar substitutes: A review of the safety issues, Comprehens. Rev. Food Sci. Food Saf., 5, 35-47 (2006).

[3] K. Clauss, H. Jensen, Oxathiazinone dioxides - A new group of sweetening agents, Angew. Chem. Int. Ed., 12, 869-876 (1973).

[4] D. G. Mayer, F. H. Kemper (Eds.), Acesulfame-K, Marcel Dekker, New York, 1991.

[5] E. F. Paulus, 6-Methyl-1,2,3,oxothiazin-4(3K)-on-2,2dioxid, Acta Crystallogr., B31, 1191-1193 (1975).

[6] E. J. Baran, V. T. Yilmaz, Metal complexes of saccharin, Coord. Chem. Rev., 250, 1980-1999 (2006).

[7] H. Içbudak, A. Bulut, N. Cetin, C. Kazak, Bis(acesulfamato)tetraaquacobalt(II), Acta Crystallogr., C61, m1-m3(2005).

[8] A. Bulut, H. Içbudak, G. Sezer, C. Kazak, Bis(acesulfamato- $\left.\mathrm{K}^{2} \mathrm{~N}^{3}, \mathrm{O}^{4}\right)$ bis(2-aminopyrimidine) $\left.\mathrm{KN}^{1}\right)$ copper(II), Acta Crystallogr., C61, m228-m230 (2005).

[9] N. Dege, H. Içbudak, E. Adiyaman, Bis(acesulfamato$\left.\mathrm{K}^{2} \mathrm{O}^{4}, \mathrm{~N}\right)$ bis(3-methylpyridine)copper)II), Acta Crystallogr., C62, m401-m403(2006).

[10] H. Içbudak, E. Adiyaman, N. Cetin, A. Bulut, O. Buyukgungor, Synthesis, structural characterization and chromotropism of a $\mathrm{Ni}$ (II) and a $\mathrm{Co}$ (II) compound with acesulfamate as a ligand, Transit. Met. Chem., 31, 666-672 (2006).

[11] H. Içbudak, E. Adiyaman, A. Uyanik, S. Cakir, Synthesis, characterization and chromotropic properties of $\mathrm{Mn}^{\mathrm{II}}, \mathrm{Co}^{\mathrm{II}}, \mathrm{Ni}^{\mathrm{II}}$ and $\mathrm{Cu}^{\mathrm{II}}$ with bis(acesulfamato)bis(3methylpyridine) complexes, Transit. Met. Chem., 32, 864-869 (2007).

[12] N. Dege, H. Içbudak, E. Adiyman, Bis(acesulfamato$\mathrm{KO}^{4}$ )diaquabis (3-methylpyridine-kN)nickel(II), Acta Crystallogr., C63, m13-m15 (2007).
[13] Z. S. Sahin, H. Içbudak, S. Isik, Di- $\mu$-acesulfamato-K ${ }^{2}$ $\mathrm{N}, \mathrm{O}: \mathrm{O} ; \mathrm{K}^{3} \quad$ O:-N,O-bis [(acesulfamato-K $\left.{ }^{2} \quad \mathrm{~N}, \mathrm{O}\right)$ bis $(3-$ methylpyridine)cadmium(II)], Acta Crystallogr., C65, m463-m465 (2009).

[14] M. Cavicchioli, A. C. Massabni, T. A. Heinrich, C. M. Costa-Neto, E. P. Abrão, B. A. L. Fonseca, E. E. Castellano, P. P. Corbi, W. R. Lustri, C. Q. F. Leite, Pt(II) and $\operatorname{Ag}(\mathrm{I})$ complexes with acesulfame: Crystal structure and a study of their antitumoral, antimicrobial and antiviral activities, J. Inorg. Biochem., 104, 533-540 (2010).

[15] G. A. Echeverría, O. E. Piro, S. B. Parajón-Costa, E. J. Baran, Synthesis and characterization of ammonium acesulfamate, Z. Naturforsch., 69b, 737-741 (2014).

[16] O. E. Piro, G. A. Echeverría, E. E. Castellano, S. B. Parajón-Costa, E. J. Baran, Structural and spectroscopic characterization of isomorphous sodium, rubidium and cesium acesulfamates, $Z$. Naturforsch. 70b, in press.

[17] S. P. Velaga, V. R. Vangala, S. Basavoju, D. Boström, Polymorphism in acesulfame sweetener: structureproperty and stability relationships of bending and brittle crystals, Chem. Commun. 46, 3562-3564 (2010).

[18] CrysAlisPro, Oxford Diffraction Ltd., version 1.171.33.48 (release 15-09-2009 CrysAlis171.NET).

[19] G. M. Sheldrick, A short history of SHELX, Acta Crystallogr. A64, 112-122 (2008).

[20] C. K. Johnson, ORTEP-II. A Fortran Thermal-Ellipsoid Plot Program. Report ORNL- 5318, Oak Ridge National Laboratory, Tennessee, USA, 1976.

[21] P. Nockemann, B. Thijs, K. Driesen, C.R. Janssen, K. Van Hecke, L. Van Meervelt, S. Kossmann, B. Kirchner, K. Binnemans, Choline saccharinate and choline acesufamate: ionic liquids with low toxicities, J. Phys. Chem. B, 111, 5254-5263 (2007).

[22] J. E. Huheey, E. A. Keiter, R. L. Keiter, Inorganic Chemistry. Principles of Structure and Reactivity, $4^{\text {th }}$.Edit., Harper-Collins, New York, 1993, pp.114-117.

[23] E. J. Baran, C. C. Wagner, M. Rossi, F. Caruso, Characterization of thallium(I) saccharinate: an unprecedented coordination of the saccharinate ligand, Z. Anorg. Allg. Chem. 627, 85-89 (2001).

[24] R. Weber, M. Gilles, G. Bergerhoff, Crystal structure of 1,2-benzisothiazol-3(2H)-one-1,1-dioxide, (saccharin) silver salt, $\mathrm{Ag}\left(\mathrm{C}_{7} \mathrm{H}_{4} \mathrm{NO}_{3} \mathrm{~S}\right), Z$. Kristallogr. 206, 273-274 (1993).

[25] A. D. Popova, E. A. Velcheva, B. A. Stamboliyska, DFT and experimental study on the IR spectra and structure of acesulfame sweetener, J. Mol. Struct. 1009, 23-29 (2012).

[26] G. Jovanovski, S. Tančeva, B. Šoptrajanov, The $\mathrm{SO}_{2}$ stretching vibrations in some metal saccharinates: spectrastructure correlations, Spectr. Lett. 28, 1095-1109 (1995).

[27] G. Jovanovski, Metal saccharinates and their complexes with N-donor ligands, Croat. Chim. Acta 73, 843-868 (2000).

[28] P. Naumov, G. Jovanovski, Vibrational study and spectra-structure correlations in ammonium saccharinate: comparison with the alkali saccharinates, Spectrochim. Acta, 56 A, 1305-1318 (2000).

[29] P. Naumov, G. Jovanovski, An update of the combined vibrational-diffraction experimental and theoretical studies of small biologically important cyclic imides: reference to saccharin, Curr. Org. Chem. 5, 1059-1077 (2001). 